\title{
Father's Involvement in Parenting as a Predictor of Adolescents' Social Adaptation
}

\author{
Nadia Miranti Kusumasari ${ }^{1}$ \\ ${ }^{1}$ Department of Psychology, Universitas Negeri Yogyakarta, \\ Jl. Colombo No. 1 Karang Malang Sleman, Yogyakarta \\ ${ }^{1}$ mirantinadia.nmk@gmail.com
}

\begin{abstract}
The purpose of this study is to determine the effect of father's involvement towards social adjustment in adolescent. This study uses quantitative approaches with the type of survey research. The population of this study are 437 students of 7th and 8th grade at MTs A Yogyakarta with 211 students as a sample which determined by simple random sampling technique. Data was collected by using father's involvement scale and social adjustment scale. Validity in the scale of this study used content validity carried out by expert. Reliability in the scale of this study used Alpha Cronbach reliability coefficient of 0,951 on the father's involvement scale and 0,905 on the social adjustment scale. As for data analysis, descriptive analysis and simple linear regression analysis are used. The results of this study showed that father's involvement has a significant contributed $27,1 \%$ towards social adjustment in adolescent $(\mathrm{F}=77,672 ; \mathrm{p}=0,000<\alpha 0.05)$. As for the line of regression equation obtained is $\mathrm{Y}=47,789+0,289 \mathrm{X}$.
\end{abstract}

Keywords: Father's Involvement, Social Adjustment, Adolescent

\section{Introduction}

Rahayu and Hartati (2015) state that during this transitional period, adolescents will more often engage in activities and interact with people outside the home compared to when they were children. Social interactions during adolescence are expanding and complex, because adolescents do not only communicate with family members, but also communicate with people in the community (Rahayu \& Hartati, 2015). In communicating with other individuals, there are two needs that encourage individuals to move into communication, namely the need to maintain their survival and the need to adapt (Fathunnisa, 2012).

According to Andriyani (2016), adjustment in adolescence begins with changes in adolescents and reactions from the environment around adolescents to adolescent growth. He further explained that the environment in question includes parents, family members, teachers, peers, and the general public who react by demanding that adolescents be able to display appropriate behavior in adolescence.

Self-adjustment is inseparable from the social context, so it can be called social adjustment, which includes adjustment to the values, norms, and consequences that exist in the environment, and being able to establish harmonious relationships with other individuals (Wicaksono, 2017). In adolescents, social adjustment starts from adjusting to other people whose previous relationships have never existed and then adjusting to adults outside the family and school environment (Purwito \& Rahmandani, 2018).

Estiane (2015) said, although not all adolescents experience periods of storms and stress, many adolescents experience instability from time to time as a consequence of adjusting to new behavior patterns and social expectations. In Yuliantini's (2017) study, adolescents who are poorly adapted to the school 


\section{Father's Involvement in Parenting \\ Nadia Miranti Kusumasari}

environment exhibit negative behaviors that are not praiseworthy, such as truancy, alcohol drinking, and getting high in the school backyard due to excessive glue huffing. These behaviors certainly pose a big risk to the dynamics of the surrounding environment. Gradually, these problem youths can form groups of friends to channel these negative behaviors and often disturb the security of the surrounding community and endanger themselves (Yuliantini, 2017).

Apart from having an effect on the increasing tendency for juvenile delinquency to form, poor adjustment in adolescents can also have an impact on adolescent anxiety in communicating with others (interpersonal). This is in line with the research of Fathunnisa (2012) which shows that adolescent adjustment has an influence on adolescent anxiety to communicate. Based on the results of the study, the adjustment variable has a negative effect of $55.8 \%$ on adolescent communication anxiety. In other words, when adolescents are less skilled in adjusting to the environment, it will increase the anxiety experienced by adolescents to communicate with others. Adolescent communication becomes disrupted, adolescents find it difficult to meet their needs, and has less friends.

Based on the results of an interview in February 2020 with a guidance and counselling teacher at MTs A Yogyakarta who said that there were a number of student behaviors that often disturbed the atmosphere of teaching and learning activities or violated school regulations. There are three cases that occur quite often, namely not doing school work, joking that offends friends, and skipping certain subjects. In the case of not doing school work and skipping certain subjects, it can be triggered by three conditions, namely students who forget to do assignments, material that is difficult for students to understand from certain subjects such as mathematics, or being influenced by students who do not like it in a way teachers who teach. However, it is not uncommon for these conditions to be in one moment at the same time, so that it further triggers students not to carry out their responsibilities. This behavior is an indication of an obstacle to students being able to adjust well in the school environment. Thus, it can be seen that the adjustment of adolescents in the junior high school environment is not easy enough for adolescents to do if the adolescents do not have adequate skills and experience in adjusting to the environment. It takes special attention from the immediate environment in assisting the development process of adolescents.

The ability of adolescents to adapt to the social environment arises through a long process and involves several factors that influence it, including social support from friends (Estiane, 2015), parenting styles (Annisa \& Masykur, 2017), the role of father and mother, trust adolescence (Ernawati \& Fadillah, 2018), social maturity (Dzakiyah, 2019), and safe attachment to father and mother (Muzdalifah, Anward, \& Rachmah, 2019). According to Annisa and Masykur (2017), the relationship between parents in the form of childcare has a very broad impact on children's social abilities, especially in terms of adjustment. In the research results of Ernawati and Fadillah (2018), it is known that the role of fathers in caring for adolescents has a greater effect on adolescent social adjustment than the role of mothers in caring for adolescents. This is indicated by the value of the contribution that was given, which was $23.8 \%$ by the role of the father, while the role of the mother contributed 16.1\%. Based on these results, it can be concluded that the role of fathers in caring for adolescents has an active and important role in adolescent social development.

In the care of adolescents, fathers are involved in building adolescent independence (Muzdalifah, Anward, \& Rachmah, 2019), creating positive youth 


\section{Father's Involvement in Parenting \\ Nadia Miranti Kusumasari}

self-esteem, strengthening adolescents' desire for achievement, developing motivation to succeed in work and in continuing their education to a higher level. higher, and meet the physiological and psychological needs of children (Partasari, Lentari, \& Priadi, 2017). In addition, adolescents find it easier to absorb the values given to them by their father, because the father has a role as a person in power, a protector against threats, an educator from a rational point of view, liaising children with the outside world, and teaching about the identification process (Astuti \& Puspitarani, 2013).

So far, the role of the father in the child's life seems to be more dominant in his activities to earn a living, which is a form of the father's responsibility to meet his child's needs. This was acknowledged by the fathers in their research Partasari, Lentari, and Priadi (2017) through a questionnaire that had been adapted by the three researchers from the paternal involvement questionnaire from a father's point of view compiled by Partasari and Lentari in 2014. The questionnaire was adapted and then developed based on the results of interviews with fathers who have children aged 16-21 years. The results of these interviews became the basis for developing items from the questionnaire. The study obtained subjects as many as 201 fathers who live in DKI Jakarta and have children who are teenagers (16-21 years). The results showed that fathers tend to play a prominent role in meeting the needs of adolescents and facilitating the development of youth talent interests. In the aspect of meeting the needs of adolescents, fathers are responsible for being punctual in paying youth education insurance, saving for teenagers' needs, and ensuring that school or college fees are paid on time. Meanwhile, in the aspect of developing youth talent interest, the father was involved in finding a course for adolescents, paying tuition fees on time, and asking about the development of adolescents during the course. Based on these two aspects, it can be seen that the involvement of fathers who are warm and spend a lot of time with adolescents is not a prominent aspect of the involvement of fathers in the care of adolescents in the study.

In the research conducted by Putra in 2018, results showed that adolescents who have fathers with high parenting involvement have an influence in the form of a good adolescent's ability to adapt socially. This is because fathers' parenting affects adolescent social adjustment through the time spent by fathers to interact with adolescents every day, followed by giving examples to adolescents on how to interact in the social environment. The longer the intensity of time that fathers spend interacting with adolescents, the greater the chance for adolescents to get examples that are shown directly by fathers on how to respond to stimuli from the environment, thus helping adolescents have new perceptions and experiences in undergoing interactions his social life. This then encourages the ability of adolescents to have better social adjustment.

One of the ways that can be done to increase the ability of adolescents who are less able to adapt to the social environment is to increase the involvement of fathers in parenting through the educational process regarding the care of adolescents. In Indonesia, especially in the Province of Yogyakarta Special Region, not many studies have examined this issue, so this research is deemed important to be conducted.

\section{Methods}

This research uses a quantitative survey approach (Creswell, 2016). Azwar (2017) argues that quantitative method is a method that emphasizes analysis of data in the form of numbers, which are then collected through measurement procedures and processed with statistical analysis. 


\section{Father's Involvement in Parenting \\ Nadia Miranti Kusumasari}

This research was conducted from September 2019 - May 2020. Data collection was carried out in February - March 2020 at Madrasah Tsanawiyah (MTs) A Yogyakarta, because there were cases of students who had adjustment difficulty at that school.

\section{Participants}

The population in this study were all $7^{\text {th }}$ and $8^{\text {th }}$ grade students of MTs A Yogyakarta in the 2019/2020 academic year, totaling 437 students. Then, as many as 211 students were selected based on simple random sampling techniques (simple random sampling) and by using the Slovin formula (Setiawati, 2017).

\section{Data Collection Technique}

The data collection technique used in this study was to use a questionnaire technique in the form of a scale with four answer choices, namely Very Fit (SS), Fit (S), Not Fit (TS), and Very Not Fit (STS). The four answer choices have different scores, namely very much in accordance with score 4, according to score 3, not according to score 2 , and very not according to score 1.

The instrument in this study used two scales, namely the scale of social adjustment and the scale of fathers' involvement in parenting. On the scale of social adjustment there are 25 statement items, while on the scale of fathers' involvement in parenting there are 35 statements.

The social adjustment scale, compiled with reference to Haber and Runyon's (1984: 10) theory of selfadjustment, states that there are five characteristics of a person's adjustment, namely: (1) a strong perception of reality, (2) the ability to cope with stress and anxiety, (3) ) positive self-image, (4) ability to express feelings, and (5) good interpersonal relationships. Meanwhile on the scale of father involvement in parenting, it is compiled by referring to Lamb, Pleck,
Charnov, and Levine's father involvement theory (2010: 67) that there are five aspects of fathers' involvement in parenting, namely: (1) being bound in positive activities, (2) warm and responsive, (3) control, (4) attention indirectly, and (5) the process of responsibility.

Bungin (2011) states that the validity of the instrument is the accuracy of the instrument against something that is measured even though it is done repeatedly and anywhere. The instrument compiled is then tested for content validity, which is a process of assessing the relevance of each questionnaire statement with the measured behavioral aspects and assessing the suitability of the overall questionnaire content with the information domain to be explored (Azwar, 2017). The process of assessing the relevance is carried out by a competent appraiser (expert judgment) (Azwar, 2017).

Instrument testing was conducted to the research sample respondents as many as at least 30 respondents aimed at testing the consistency and accuracy of the measurement instruments (Noor, 2011: 164). The statement items on the instrument go through the item selection stage by taking into account the item-total correlation value using the Statistical Package for Social Science (SPSS) program. If the statement item has an item-total correlation value $\geq 0.30$, then the item is said to be accurate and consistent (Azwar, 2012). Based on the results of the item selection, 7 items were dropped on the social adjustment scale out of a total of 32 items and 3 failed on the scale of fathers' involvement in parenting, out of a total of 38 points.

Azwar (2012) stated that reliability refers to the reliability or consistency of measuring results, which implies how high the accuracy of the measurement is. Instruments that can be said to be reliable are those that have a reliability coefficient value in the range of 0 to 1 . If the instrument has a reliability coefficient value 
that is closer to number 1 , then the instrument has reliable measurement results (Azwar, 2012). Based on the reliability estimation on the social adjustment scale and the scale of fathers 'involvement in parenting, the results obtained in the form of a reliability coefficient value on the social adjustment scale of 0.905 and 0.951 on the scale of fathers' involvement in parenting.

\section{Data Analysis}

The data obtained were then analyzed descriptively, namely data analysis which aims to provide a description of the data from the variables obtained through the research subject group and is not intended to conduct hypothesis testing (Azwar, 2017: 199). Then, the data is converted into interval data through manual calculation using the following Azwar (2012) categorization norms:

Tabel 1. Norm for Categorization

\begin{tabular}{cc}
\hline Category & Formula \\
\hline Very High & $\mathrm{X}>\mu+1,5 \sigma$ \\
\hline High & $\mu+0,5 \sigma<\mathrm{X} \leq \mu+1,5 \sigma$ \\
\hline Average & $\mu-0,5 \sigma<\mathrm{X} \leq \mu+0,5 \sigma$ \\
\hline Low & $\mu-1,5 \sigma<\mathrm{X} \leq \mu-0,5 \sigma$ \\
\hline Very Low & $\mathrm{X} \leq \mu-1,5 \sigma$ \\
\hline
\end{tabular}

In this study, no assumption test analysis was carried out on the data obtained in the field. Based on the explanation of Sari, Sukestiyarno, and Agoestanto (2017), it is stated that the data to be analyzed in statistical inference is considered to fulfill the assumptions required for computational formulations. The analysis can be carried out without having to first check whether or not the assumptions concerned are fulfilled in the hypothesis test analysis (Sari, Sukestiyarno \& Agoestanto, 2017).

According to Setiawati (2017), research hypothesis testing is related to the probability of acceptance or rejection of the hypothesis. This research hypothesis test used simple regression analysis test with the help of the SPSS program because this study consisted of one predictor variable $(\mathrm{X})$ and one criterion variable $(\mathrm{Y})$ and this study aims to determine how far the influence of the predictor variable $(\mathrm{X})$ on the criterion variable $(\mathrm{Y})$, so using the formula $\mathrm{Y}=\mathrm{a}+\mathrm{bX}$ (Setiawati, 2017).

\section{Findings and Discussion}

The research data were obtained from 211 7th and 8th grade students at MTs A Yogyakarta with the following details:

Table 2. Research Subject Data Based on Age

\begin{tabular}{ccc}
\hline Age & Freq & $\mathbf{\%}$ \\
\hline 12 & 22 & $10,42 \%$ \\
\hline 13 & 97 & $45,97 \%$ \\
\hline 14 & 80 & $37,91 \%$ \\
\hline 15 & 12 & $5,7 \%$ \\
\hline Total & $\mathbf{2 1 1}$ & $\mathbf{1 0 0 \%}$ \\
\hline
\end{tabular}

Based on Table 2, it is known that the subjects in this study were between 12 15 years old. Most of the subjects were 1314 years old, as many as 97 people (45.97\%) at the age of 13 years and as many as 80 people $(37.91 \%)$ at the age of 14 years. Meanwhile, the subjects aged 12 and 15 years, as many as 22 people $(10.42 \%)$ at the age of 12 years and as many as 12 people $(5.7 \%)$ at the age of 15 years.

Then, the data that has been collected is analyzed descriptively. Descriptive analysis is calculated by manual counting based on categorization norms proposed by Azwar (2012: 148). Based on these calculations, the following results were obtained:

Table 3. Description of Social Adjustment Data $(Y)$

\begin{tabular}{cc}
\hline Descriptive & Skor \\
\hline Mean $(\mu)$ & 78,75 \\
\hline Standard Deviation $(\sigma)$ & 8,818 \\
\hline Maximum & 100 \\
\hline
\end{tabular}




\begin{tabular}{ll}
\hline Minimum & 57
\end{tabular}

Based on Table 3, it is known that the highest score on the social adjustment variable is 100 and the lowest score is 57. Mean is 78.75 with standard deviation of 8.818. Then, proceed with the calculation based on the categorization norm.

Tabel 4. Results of Social Adjustment Categorization

\begin{tabular}{cccc}
\hline Category & Range & Freq & $\mathbf{0}$ \\
\hline Very High & $\mathrm{X}>91,97$ & 13 & $6,16 \%$ \\
\hline High & $83,15<\mathrm{X} \leq 91,97$ & 52 & $24,65 \%$ \\
\hline Average & $74,341<\mathrm{X} \leq 83,15$ & 82 & $38,86 \%$ \\
\hline Low & $65,52<\mathrm{X} \leq 74,341$ & 49 & $23,22 \%$ \\
\hline Very Low & $\mathrm{X} \leq 65,52$ & 15 & $7,11 \%$ \\
\hline & Total & $\mathbf{2 1 1}$ & $\mathbf{1 0 0 \%}$ \\
\hline
\end{tabular}

Based on Table 4, it is known that the most frequent frequencies are in the average category $(74.341<\mathrm{X} \leq 83.15)$ with a total of 82 students $(38.86 \%)$.
Meanwhile, the lowest frequency was in the very high category $(X>91.97)$ with 13 students $(6.16 \%)$.

Table 5. Result of Social Adjustment Characteristics Score

\begin{tabular}{lcc}
\hline \multicolumn{1}{c}{ Characteristics } & $\begin{array}{c}\text { Total } \\
\text { Score }\end{array}$ & $\begin{array}{c}\text { Character } \\
\text { Score }\end{array}$ \\
\hline Strong reality principles & 3443 & $20,72 \%$ \\
\hline Able to cope with stress and anxiety & 3966 & $23,87 \%$ \\
\hline Positive self-image & 3490 & $21 \%$ \\
\hline Ability to express feelings & 1180 & $7,10 \%$ \\
\hline Good interpersonal relationship & 4538 & $27,31 \%$ \\
\hline \multicolumn{1}{c}{ Total } & $\mathbf{1 6 6 1 7}$ & $\mathbf{1 0 0 \%}$ \\
\hline
\end{tabular}

Based on Table 5, it is known that the characteristics of a good interpersonal relationship are the characteristics with the highest score, which is $27.31 \%$. Meanwhile, the characteristic of the ability to express feelings was the aspect with the lowest score, amounting to $7.10 \%$.
Table 6. Data Description of Father's Involvement in Parenting $(\mathrm{X})$

\begin{tabular}{cc}
\hline Descriptive & Skor \\
\hline Mean $(\mu)$ & 107,17 \\
\hline Standard Deviation $(\sigma)$ & 15,88 \\
\hline Maximum & 139 \\
\hline Minimum & 35 \\
\hline
\end{tabular}

Based on Table 6, it is known that the highest score on the variable of father involvement in parenting is 139 and the lowest score is 35 . Mean is 107.17 with a standard deviation of 15.88. Then, proceed with the calculation based on the norm of categorization. 
Table 7. Results of the Categorization of Father's Involvement in Parenting

\begin{tabular}{|c|c|c|c|}
\hline Category & Range & Freq & $\%$ \\
\hline Very High & $X>131$ & 9 & $4,27 \%$ \\
\hline High & $115,12<\mathrm{X} \leq 131$ & 55 & $26,07 \%$ \\
\hline Average & $99,24<\mathrm{X} \leq 115,12$ & 97 & $45,97 \%$ \\
\hline Low & $83,36<\mathrm{X} \leq 99,24$ & 34 & $16,11 \%$ \\
\hline Very Low & $\mathrm{X} \leq 83,36$ & 16 & $7,58 \%$ \\
\hline \multicolumn{2}{|r|}{ Total } & 211 & $100 \%$ \\
\hline
\end{tabular}

Based on Table 7, it is known that the most frequent frequencies are in the average category $(99.24<\mathrm{X} \leq 115.12)$ with 97 students (45.97\%). Meanwhile, the lowest frequency was in the very high category with 9 students $(4.27 \%)$.

Table 8. Results of the Scores of Father Involvement Aspects in Parenting

\begin{tabular}{lcc}
\hline \multicolumn{1}{c}{ Aspects } & $\begin{array}{c}\text { Total } \\
\text { Score }\end{array}$ & $\begin{array}{c}\text { Character } \\
\text { Score }\end{array}$ \\
\hline Bound with positive activities & 6198 & $27,41 \%$ \\
\hline Warm and responsive & 3128 & $13,83 \%$ \\
\hline Control & 5419 & $23,96 \%$ \\
\hline Indirect attention & 5176 & $22,89 \%$ \\
\hline Responsibility process & 2693 & $11,91 \%$ \\
\hline \multicolumn{1}{c}{ Total } & $\mathbf{2 2 6 1 4}$ & $\mathbf{1 0 0 \%}$ \\
\hline
\end{tabular}

Based on Table 8, it is known that the bound aspect of positive activities is the aspect with the highest score, which is equal to $27.41 \%$. Meanwhile, the responsibility process aspect was the aspect with the lowest score, which was $11.91 \%$.
Then, a hypothesis is tested on the data that has been obtained. Hypothesis testing in this study was carried out using simple linear regression analysis with the help of the SPSS program to test the influence of fathers' involvement in parenting on social adjustment.

Table 9. ANOVA Result for Regression Analysis

\begin{tabular}{lccccc}
\hline \multicolumn{1}{c}{ Model } & $\begin{array}{c}\text { Sum of } \\
\text { Squares }\end{array}$ & df & $\begin{array}{c}\text { Mean } \\
\text { Square }\end{array}$ & F & Sig. \\
\hline \multicolumn{1}{c}{$\begin{array}{l}\text { Regression } \\
1\end{array}$ Residual } & 4424.82 & 1 & 4424.82 & 77.67 & .00 \\
$\quad$ Total & 11906.37 & 209 & 56.97 & & \\
\hline
\end{tabular}

Based on Table 9, it is known that the $\mathrm{F}$ value in this simple linear regression analysis shows a value of 77.672 with a significance value of 0.000 . That is, the significance value is less than 0.05 . These results indicate that the regression line equation is significant. Thus, it can be concluded that the involvement of fathers in parenting (X) can predict social adjustment $(\mathrm{Y})$. 
Trial Application of Acceptance Afada Alhaque ${ }^{1}$, Poeti Joefiani', Esti Wungu ${ }^{3}$

Table 10. Results of the coefficient of determination

\begin{tabular}{ccccc}
\hline \multicolumn{5}{c}{ Model Summary } \\
\hline Model & $\mathrm{R}$ & R Square & $\begin{array}{l}\text { Adjusted } \\
\text { R Square }\end{array}$ & $\begin{array}{c}\text { Std. Error of } \\
\text { the Estimate }\end{array}$ \\
\hline 1 & .521 & .271 & .267 & 7.548 \\
\hline
\end{tabular}

Based on Table 10, it is known that the coefficient of determination ( $R$ Square) is 0.271 . These results indicate that the contribution of fathers' involvement in parenting in influencing social adjustment is $27.1 \%$. Meanwhile, for the other $72.9 \%$ it is a contribution from other factors not examined in this study. In addition, it can also be seen that the value of the Standard Error of Estimate is 7.548. That is, the smaller the value, the more precise the regression model will be in predicting the criterion variable.

Table 11. Results of Linear Regression Analysis

\begin{tabular}{cccccc}
\hline \multirow{2}{*}{ Model } & \multicolumn{2}{c}{$\begin{array}{c}\text { Unstandardized } \\
\text { Coefficients }\end{array}$} & $\begin{array}{c}\text { Standardized } \\
\text { Coefficients }\end{array}$ & $\mathrm{t}$ & Sig. \\
\cline { 2 - 6 } & $\mathrm{B}$ & $\begin{array}{c}\text { Std. } \\
\text { Error }\end{array}$ & Beta & & \\
\hline 1 & 47.789 & 3.552 & & 13.455 & .000 \\
\hline $\begin{array}{c}\text { Father's involvement } \\
\text { in parenting }\end{array}$ & .289 & .033 & .521 & 8.813 & .000 \\
\hline
\end{tabular}

Based on Table 11, it is known that the constant score is 47.789 and the regression coefficient is 0.289 . These results indicate the condition of the regression line in this study. To obtain the regression line equation, it can be done by using the formula $\mathrm{Y}=\mathrm{a}+\mathrm{bX}$. Based on this formula, the regression line equation is obtained, namely $\mathrm{Y}=47.789+0.289 \mathrm{X}$. The meaning of the regression line equation according to Misbahuddin and Hasan (2013) is as follows:

a. Constant (a) $=47,789$

If the Father's Involvement in Parenting $(\mathrm{X})$ is equal to zero (no change) then the Social Adjustment $(Y)$ is 47,789 .

b. Regression Coefficient (b) $=+0.289$

The regression coefficient shows a positive value which means that the higher the involvement of the father in parenting $(\mathrm{X})$, the higher the social adjustment (Y). In addition, if Father's Involvement in Parenting (X) increases by 1 unit, then Social Adjustment (Y) will increase by 0.289. This means that if the Father's Involvement in Parenting increases by 0.289 , then the Social Adjustment will increase by 0.289 .

Based on the hypothesis test using simple linear regression analysis, it can be concluded that the involvement of fathers in parenting $(\mathrm{X})$ affects social adjustment $(\mathrm{Y})$. The involvement of the father in parenting $(\mathrm{X})$ has a positive effect on social adjustment $(\mathrm{Y})$ by $27.1 \%$. This positive effect shows that the higher the involvement of the father in parenting, the better the social adjustment. These results indicate that the hypothesis in this study is accepted. 


\section{Father's Involvement in Parenting \\ Nadia Miranti Kusumasari}

\section{Discussion}

The data analysis of this study shows that the involvement of fathers in parenting has an effect on adolescent social adjustment. In other words, the hypothesis in this study, which states that there is an effect of fathers' involvement in parenting on adolescent social adjustment, is proven and accepted. In addition, the results of the analysis also show that the involvement of fathers in parenting positively affects adolescent social adjustment. This means that the higher the father is involved in caring for adolescents, the higher the adolescent's ability to make social adjustments. The results of this analysis are in line with the results of Putra's (2018) research that the involvement of fathers in parenting has a positive effect on the social adjustment of adolescents in Malang City, East Java.

The father shows his involvement in caring for adolescents by engaging in positive activities with adolescents, being warm and responsive to adolescents, controlling adolescent behavior, giving indirect attention to adolescents, and being responsible for the sustainability of the youth care process (Pleck, in Lamb, 2010: 67). In general, most teenagers have felt quite well about the involvement of their fathers in their care.

The results showed that fathers often play a role in engaging in positive activities with adolescents, thus making adolescents have experience in communicating with fathers, obtaining guidance from fathers when learning new things, doing physical activities together, getting support from fathers. when adolescents do something, to get help from fathers when they are teenagers have problems. Adolescents who are often involved in activities with their fathers, have a greater sense of empathy, are more sensitive to the needs and rights of others, are more able to control themselves, are helpful, and are able to face and overcome difficult life situations (Falceto \& Galambos, in Murdani, Rinaldi, \& Yusra, 2015). In addition, the frequent interactions between fathers and adolescents have made most adolescents able to establish healthy interpersonal relationships with school members. This is in accordance with Putra's (2018) statement that through intense interaction with fathers, it gives adolescents the opportunity to be able to learn directly about how to socialize with other people as exemplified by the father. This healthy interpersonal relationship can be seen from the good adolescent ability to accept other people as they are, support and help school residents, share emotions with their peers, and establish good communication with school members.

Even so, a number of these things tend to be difficult for adolescents to have optimally because fathers tend to have less role in involving their affection during activities with adolescents. Based on the theory of father involvement in parenting (Pleck, in Lamb, 2010: 67), it is explained that the father's warmth and responsiveness to the child is related to the father's attachment to activities with the child. This means that in the direct interaction that exists between father and son, there is a father's warmth and responsiveness to his child. The results of the analysis show that fathers do not use or express aspects of their affection in warm interactions and respond to the needs of adolescents well during their interaction together. This makes adolescents feel less affectionate by their father for adolescents, father's appreciation of what adolescents have done, father's sensitivity to changes in adolescent conditions, father is slow in knowing and meeting adolescent's needs. On the other hand, adolescents tend to be minimal to express their feelings. 


\section{Father's Involvement in Parenting \\ Nadia Miranti Kusumasari}

The condition of the lack of fathers in being warm and sensitive to the needs of adolescents and the lack of adolescents to express their feelings are related to how the character and personality of adolescents are formed in their activities. This is in accordance with the results of research by Lestari, Nursetiawati, and Utami (2015) that the warm and supportive attitude of the father in giving affection to children is related to the formation of children's character in cultivating the child's heart, mind, body, and feelings. Although not done permanently, neglect of the need for affection can increase discomfort in adolescents in the form of worry, fear, irritability, and anger, cause mental instability in adolescents, and provide less cognitive stimulation for adolescents (Harmaini, Shofiah, \& Yulianti, 2014) .

Although fathers play a big role in meeting the material and social needs of adolescents, fathers have also been shown to play a minimal role in having sensitivity in knowing and responding responsively to adolescent's needs. Fathers do not play a role in taking the initiative to find out the needs of adolescents, so that the needs of adolescents tend to be difficult for fathers to respond to immediately. There are obstacles in fulfilling their needs, making adolescents have the ability to deal with low stress and anxiety. Harmaini, Shofiah, and Yulianti (2014) state that through the support of the father in meeting the material needs of the child, this can reduce the stress experienced by the child because if problems arise in meeting the material needs, it can be resolved immediately. This means that the less than optimal support from fathers in meeting the needs of adolescents, namely the lack of fathers to play a responsive role and to take the initiative to the needs of adolescents, triggers increased stress and adolescent anxiety. This makes adolescents less able to make their life goals the direction of life, refrain from the temptation to quickly achieve goals, and overcome problems that arise during the process of achieving goals.

Furthermore, if parents are able to be thorough, understand, and respond appropriately to the signs conveyed by children through communication, this will make the child feel safe and have a sense of trust in the environment, which then creates confidence in the child to explore his environment (Andayani \& Koentjoro, 2014: 21). That is, fathers who do not play a role in responding to the needs of adolescents well, making adolescents feel insecure and distrustful of their environment, thus triggering the low selfconfidence of adolescents in exploring their surroundings. Low self-confidence leads to bad behavior and triggers failure in adolescent social adjustment (Hurlock, in Ernawati \& Fadillah, 2013) and has a positive effect on the self-image of adolescents (Ramadhani \& Putrianti, 2014). This is in line with the results of research which shows that adolescents are low in having a positive self-image. The low self-image of adolescents can be seen from their inability to assess, accept, and modify their strengths and weaknesses.

Even so, the tendency of adolescents to behave deviantly during their school days can be minimized because of the high control by fathers of adolescents (Miller et al., In Andayani \& Koentjoro, 2004; in Haque, 2014). The father's firm attitude in controlling these adolescents stems from the enactment of rules regarding what teenagers can and cannot do in their daily lives and the consequences of violating them. This encourages adolescents to have realistic perceptions and goals for activities, making it easier for them to recognize the consequences of decisions about the goals chosen by adolescents. After adolescents understand the rules that apply and their consequences, the father continues the control process by overseeing the implementation of these rules. The 
supervision process is carried out by the father by ensuring the clarity of the activities carried out by the teenager and the destination of the location when the teenager will travel, constantly reminding teenagers to be disciplined in routine activities, to trying to find out where the teenager is when they are difficult to contact. When adolescents break the rules, fathers are also strict in disciplining them. With the strict application of the rules by the father, it makes teenagers accustomed to being able to act based on careful consideration. This is in line with the opinion of Astuti and Puspitarani (2013) that it is easier for adolescents to absorb the values given to them by the father, because the father has a role as a person in power, a protector against threats, an educator from a rational perspective, a liaison for children with the outside world, and teaches about the identification process.

Based on the analysis, it is known that the involvement of fathers in parenting affects the social adjustment of adolescents by $27.1 \%$. Meanwhile, the other $72.9 \%$ are influenced by other factors that were not examined in this study. This means that the involvement of fathers in the care of adolescents contributed $27.1 \%$ to the formation of adolescent social adjustment. In other words, one of the things that can be done so that adolescents have good social adjustment is to increase the involvement of fathers in caring for teenagers.

Meanwhile, there are $72.9 \%$ others who can influence adolescent social adjustment. This is because the involvement of fathers in parenting is not the only factor that can influence social adjustment. Other factors that can influence adolescent social adjustment include personality factors, physical conditions, development and maturity, psychological conditions, environmental conditions, and culture and religion (Schneiders, 1960: 122).

\section{Conclusion}

Based on this research, the results of the analysis show that the involvement of fathers in parenting is proven to affect social adjustment in adolescents as indicated by the value of $F=77.672$ with a significance value of 0.000 , so that it is less than 0.05 . The involvement of fathers in parenting contributed $27.1 \%$ to adolescent social adjustment. This means that if adolescents have fathers who are well involved in caring for adolescents, it can be predicted that social adjustment in adolescents also tends to be good. Meanwhile, if adolescents have fathers who are poorly involved in caring for adolescents, it can be predicted that the social adjustment of adolescents also tends to be less good.

\section{References}

Andayani, B., \& Koentjoro. (2014). Peran Ayah Menuju Coparenting. Sidoarjo: Laros.

Andriyani, J. (2016). Korelasi Peran Keluarga terhadap Penyesuaian Diri Remaja. Jurnal Al-Bayan, 22(34), 39-52.

Annisa, M. A., \& Masykur, A. M. (2017). Hubungan antara Persepsi terbadap Peran Ayab dan Penyesuaian Sosial pada Siswa Kelas XI SMA Islam Hidayatullab Semarang. Jurnal Empati, 6(1), 296-300.

Astuti, V., \& Puspitarani, P. (2013). Keterlibatan Ayah dalam Pengasuban Jarak Jauh Remaja. Prosiding Seminar Nasional Parenting, (pp. 121-131).

Azwar, S. (2012). Penyusunan Skala Psikologi (edisi II). Yogyakarta: Pustaka Pelajar.

Azwar, S. (2017). Metode Penelitian Psikologi (edisi II). Yogyakarta: Pustaka Pelajar. 


\section{Father's Involvement in Parenting \\ Nadia Miranti Kusumasari}

Bungin, B. (2011). Metodologi Penelitian Kuantitatif Komunikasi, Ekonomi dan Kebijakan Publike serta Ilmu-Ilmu Sosial Lainnya (edisi kedua). Jakarta: Kencana Predana Grup.

Creswell, J. W. (2016). Research Design: Pendekatan Metode Kualitatif, Kuantitatif, dan Campuran. Yogyakarta: Pustaka Pelajar.

Dzakiyah, F. (2019). Pengaruh Kematangan Sosial terhadap Penyesuaian Diri Siswa SMP Negeri 2 Sewon. Jurnal Riset Mahasiswa Bimbingan dan Konseling, 5(8), 581-591.

Ernawati, \& Fadillah, G. F. (2018). Penyesuaian Sosial Remaja Ditinjau dari Peran Ibu Ayah dan Kepercayaan Diri pada Remaja. Jurnal Studi Islam, 19(1), 1-5.

Estiane, U. (2015). Pengaruh Dukungan Sosial Sahabat terhadap Penyesuaian Sosial Mahasiswa Baru di Lingkungan Perguruan Tinggi. Jurnal Psikologi Klinis dan Kesehatan Mental, 4(1), 29-40.

Fathunnisa, A. (2012). Pengaruh Penyesuaian Diri terhadap Kecemasan Komunikasi Interpersonal pada Remaja di Panti Asuhan Muslimin. Jurnal Penelitian dan Pengukuran Psikologi, 1(1), 135-142.

Haber, A., \& Runyon, R. P. (1984). Psychology of Adjustment. Illinois: The Dorsey Press.

Haque, E. A. (2014). Hubungan antara Keterlibatan Ayah dalam Pengasuban dan Kecerdasan Emosional dengan Perilaku Prososial pada Remaja. Character: Jurnal Penelitian Psikologi, 2(1).

Harmaini, Shofiah, V., \& Yulianti, A. (2014). Peran Ayah dalam Mendidik Anak. Jurnal Psikologi, 10(2), 80-85.
Lamb, M. E. (2010). The Role of Father in Child Development (fifth edition). New Jersey: John Wiley \& Sons Inc.

Lestari, W., Nursetiawati, S., \& Utami, V. (2015). Hubungan antara Keterlibatan Ayah dengan Pembentukan Karakter Remaja. Jurnal Kesejahteraan Keluarga dan Pendidikan, 4(1), 36-43.

Misbahuddin, \& Hasan, I. (2013). Analisis Data Penelitian dengan Statistik (Kedua ed.). Jakarta: Bumi Aksara.

Murdani, S., Rinaldi, \& Yusra, Z. (2015). Hubungan Keterlibatan Ayah dalam Pengasuhan (Father Involvement) dengan Penyesuaian Diri Remaja. Jurnal Riset Psikologi.

Muzdalifah, R., Anward, H. H., \& Rachmah, D. N. (2019). Peranan Kelekatan Aman pada Ayah dan Ibu terhadap Penyesuaian Diri Santriwati. Jurnal Psikologi Pendidikan \& Konseling, 5(1), 4956. doi:10.26858/jppk.v5il.6832

Noor, J. (2011). Metodologi Penelitian: Skripsi, Tesis, Disertasi, dan Karya Ilmiah (pertama, cetakan ke-1 ed.). Jakarta: Kencana.

Partasari, W. D., Lentari, F. R., \& Priadi, M. A. (2017). Gambaran Keterlibatan Ayah dalam Pengasuban Anak Usia Remaja (Usia 16-21 Tabun). Jurnal Psikogenesis, 5(2), 159-167.

Purwito, A. W., \& Rahmandani, A. (2018). Hubungan Kecerdasan Emosional dengan Penyesuaian Sosial Siswa Boarding School Pondok Pesantren Muijaddadiyah Kota Madiun. Jurnal Empati, 7(2), 328333.

Putra, K. M. (2018). Pengarub Keterlibatan Ayah dalam Pengasuban terbadap Penyesuaian Sosial Remaja. Skripsi, dipublikasikan. Universitas Muhammadiyah Malang. 
Rahayu, P. P., \& Hartati, S. (2015). Dukungan Sosial Ayah dengan Penyesuaian Sosial pada Remaja LakiLaki. Jurnal Empati, 4(4), 334-339.

Ramadhani, T. N., \& Putrianti, F. G. (2014). Hubungan antara Kepercayaan Diri dengan Citra Diri pada Remaja Akbir. Jurnal SPIRITS, 4(2), 22-32. Retrieved from https://media.neliti.com/media/pu blications/256852-hubunganantara-kepercayaan-diri-dengand719764a.pdf

Sari, A. Q., Sukestiyarno, Y. L., \& Agoestanto, A. (2017). Batasan Prasyarat Uji Normalitas dan Uji Homogenitas pada Model Regresi Linear. Unnes Journal of Mathematics, 6(2), 168-177.

Schneiders, A. A. (1960). Personal Adjustment and Mental Health. New York: Holt, Reinhart and Winston.

Setiawati, F. A. (2017). Statistika Terapan untuk Penelitian Pendidikan dan Sosial. Yogyakarta: Parama Publishing.

Wicaksono, I. A. (2017). Pengaruh Kualitas Kelekatan Ayab-Ibu dan Dukungan Sosial terhadap Kualitas Penyesuaian Diri Santri SLTA Kelas X Pesantren Tebuireng Jombang. Skripsi, dipublikasikan. Universitas Islam Negeri Maulana Malik Ibrahim Malang.

Yuliantini, S. (2017). Hubungan Kecerdasan Emosi dan Penyesuaian Sosial dengan Kenakalan Remaja pada Siswa SMP PGRI 7 Samarinda Seberang. Psikoborneo, 5(2), 386-399. 